\title{
A DIDÁTICA NAS TEORIAS PEDAGÓGICAS: FUNDAMENTOS E CONTRIBUIÇÕES DA DIDÁTICA CRÍTICA NA FORMAÇÃO DE PROFESSORES E APROXIMAÇÕES COM A PEDAGOGIA HISTÓRICO-CRITICA
}

\author{
Débora Villetti Zuck ${ }^{1}$, Claudimara Cassoli Bortoloto ${ }^{2}$ \\ ${ }^{1}$ Doutoranda em Educação pela Universidade Estadual de Campinas - UNICAMP. Atua como pedagoga na \\ Universidade Federal da Integração Latino-Americana (UNILA). \\ ${ }^{2}$ Doutora em Ciências Sociais pela Universidade Estadual Paulista - Unesp, campus de Araraquara. Atua como \\ professora na Universidade Tecnológica Federal do Paraná - UTFPR.
}

\section{RESUMO}

Este trabalho objetiva compreender as contribuições da Didática Crítica para a formação de professores. Para tanto, metodologicamente, a partir de pesquisa de fonte bibliográfica, tomando como recurso a revisão bibliográfica e a análise de conteúdo de materiais de natureza teórica, abrangendo um conjunto de autores, aborda o que é Didática e qual sua função na formação de professores, no âmbito teórico-prático, para o processo de ensino-aprendizagem. Trata-se de um objeto de estudo atrelado a questões não meramente técnicas, mas de cunho político-pedagógico da educação, imbricado em relações sociais. Como resultado dos impactos das transformações sociais e educacionais, ao longo do contexto histórico, a Didática em distintas teorias pedagógicas também se altera. Considerando sua não neutralidade, vincula-se a determinados objetivos, finalidades e concepções de educação. Logo, é orientada por determinados fundamentos teórico-metodológicos e pode estar em sintonia com processos de conservação ou de transformação social. Esse estudo evidencia a relevância da Didática Crítica enquanto componente indispensável na formação e prática pedagógica, que pode ser um instrumento de resistência e luta para o desenvolvimento da consciência político-pedagógica do professor comprometido com a transmissão e apropriação pelos estudantes de formas mais elaboradas de conhecimentos científicos, filosóficos e artístico-culturais, atrelada a dimensão histórica e aos determinantes da educação, pressupostos na pedagogia histórico-crítica.

Palavras-chave: Didática. Método. Formação de Professores. Pedagogia Histórico-Crítica.

\section{THE DIDACTICS IN PEDAGOGICAL THEORIES: FOUNDATIONS AND CONTRIBUTIONS OF CRITICAL DIDACTICS IN TEACHER TRAINING AND APPROACHES TO HISTORICAL-CRITICAL PEDAGOGY}

\begin{abstract}
This paper aims to understand the contributions of Critical Didactics to teacher training. Therefore, methodologically, based on a bibliographical source research, taking as a resource bibliographical review and content analysis of theoretical materials, covering a set of authors, tackles what Didactics is and what its relationship with teacher education is within the theoretical-practicum context. The study sheds light on an object of study that is intertwined not to merely technical issues, but of political-pedagogical nature, entrenched to social relations. As a result of the impacts of social and educational transformations, along the historical context, didactics in different pedagogical theories also changes. Considering its nonneutrality, it is linked to certain objectives, purposes and conceptions of education. Therefore, it is guided by certain theoretical-methodological foundations and may be in tune with processes of conservation or social transformation. This study highlights the relevance of Critical Didactics as an indispensable component in pedagogical training and practice, which can be an instrument of resistance and fight for the development of the political-pedagogical conscience of the teacher engaged with transmission and
\end{abstract}


appropriation by students of more elaborated forms of scientific, philosophical and artistic-cultural knowledge, linked to the historical dimension and the determinants of education, presupposed in Historical-Critical Pedagogy.

Keywords: Didactics. Method. Teacher education. Historical-Critical Pedagogy.

\section{LA DIDÁTICA EN LAS TEORÍAS PEDAGÓGICAS: FUNDAMENTOS Y CONTRIBUCIONES DE LA DIDÁCTICA CRÍTICA EN LA FORMACIÓN DE PROFESORES Y APROXIMACIONES CON LA PEDAGOGÍA HISTÓRICO- CRÍTICA}

Resumen: Este trabajo objetiva comprender las contribuciones de la Didáctica Crítica para la formación de profesores. Para tanto, metodológicamente, a partir de investigación de fuente bibliográfica, tomando como recurso la revisión bibliográfica y el análisis de contenido de materiales de naturaleza teórica, abarcando un conjunto de autores, se aborda lo que és Didática y cuál su función en la formación de profesores en el ámbito teórico-práctico, para el proceso de enseñanza-aprendizaje. Se trata de un objeto de estudio vinculado a cuestiones no meramente técnicas, sino de cuño político-pedagógico de la educación, imbricado en relaciones sociales. Como resultado de los impactos de las transformaciones sociales y educativas, a lo largo del contexto histórico, la Didáctica en distintas teorías pedagógicas también se altera. Considerando su no neutralidad, se vincula a determinados objetivos, finalidades y concepciones de educación. Por lo tanto, está orientada por determinados fundamentos teórico-metodológicos y puede estar en sintonía con procesos de conservación o de transformación social. Este estudio evidencia la relevancia de la Didáctica Crítica como componente indispensable en la formación y práctica pedagógica, que puede ser un instrumento de resistencia y lucha para el desarrollo de la conciencia político-pedagógica del profesor comprometido con la transmisión y apropiación por los estudiantes de formas más elaboradas de conocimientos científicos, filosóficos y artístico-culturales, vinculada a la dimensión histórica y a los determinantes de la educación, presupuestos en la Pedagogía Histórico-Crítica.

Palabras clave: Didáctica. Método. Formación de Professores. Pedagogía Histórico-Crítica.

\section{INTRODUÇÃO}

No âmbito da formação de professores a Didática tem, ou deveria ter, como função central possibilitar conhecimentos teórico-práticos que permitam a compreensão e a organização do processo de ensino-aprendizagem na educação formal.

A organização do trabalho pedagógico, a qual a Didática está inserida, abrange tanto o trabalho desenvolvido em sala de aula, especificamente, e na escola e/ou universidade em seu projeto político-pedagógico de curso e/ou institucional, globalmente, sendo permeada por disputas em torno das concepções de mundo, de homem, de sociedade e de educação, entre outras.

$\mathrm{Na}$ atuação de diversas áreas e em diferentes níveis e modalidades de ensino, ocorre que a falta de conhecimentos didáticos não é questão rara e se expressa em situações nas quais, muitas vezes, os professores "sabem para si" os conteúdos específicos de suas áreas ou "não sabem explicá-los" aos estudantes. Ou seja, o domínio dos conteúdos específicos das áreas do conhecimento não é garantia de saber as formas adequadas de transmiti-lo nem de apreensão dos elementos que perpassam o processo de ensinoaprendizagem.

Vale mencionar que, a preocupação formativa não deve ser apenas com o imediato e prático, ou, por outro lado, com aspectos teóricos, desconsiderando as questões que a realidade impõe. Por isso, compreende-se e justifica-se que é relevante apreender dialeticamente as contribuições da Didática na formação de professores, o que remete a apropriação de conhecimentos necessários para o exercício da docência enquanto profissional, inserido num contexto histórico e com finalidades determinadas.

Essa apropriação, por sua vez, começa na formação inicial e se estende para a formação continuada, momentos interligados de um mesmo processo de aprendizado e 
desenvolvimento humano, o qual não está isento de posições. No âmbito educativo, enquanto relação social, o fazer e o pensar de determinado período histórico são determinados socialmente, assim como o conteúdo e a forma do ensino, a relação entre educação e sociedade, a concepção de teoria e prática, portanto, o que é priorizado e o que é relegado à margem na formação, bem como a perspectiva Didática adotada.

Como se sabe, ao longo da história, "as circunstâncias fazem os homens, assim como os homens fazem as circunstâncias" (MARX; ENGELS, 2007, p. 43). Os homens fazem a história, em condições determinadas, são produto das circunstâncias e da educação, ao mesmo tempo em que "as circunstâncias são modificadas precisamente pelos homens e que 0 próprio educador precisa ser educado", pois não cria o conteúdo de si próprio, por isso, a mudança é a prática revolucionária (MARX; ENGELS, 2007, p. 537-538). Assim, "se as circunstâncias em que este indivíduo evoluiu só lhe permitem um desenvolvimento unilateral [...] só conseguirá alcançar um desenvolvimento unilateral e mutilado" (MARX; ENGELS, 1992, p. 28).

Nessa perspectiva, a educação, entendida como uma "atividade mediadora da prática social global, estando sempre referida a uma dada sociedade situada historicamente", deve preocupar-se com a elevação do nível cultural das massas (SAVIANI, 2007 apud MARSIGLIA; MARTINS; LAVOURA, 2019, p. 6). Isso significa que a educação cumpre a função de:

[...] promover o máximo desenvolvimento das capacidades afetivocognitivas dos indivíduos, dando-lhes condição para a transformação social. A pedagogia histórico-crítica não dá à educação o poder de transformação social direta (por isso ela é mediadora) e nem às consciências uma operacionalidade autônoma e independente das estruturas sociais. Por isso, para a pedagogia histórico-crítica, a educação deve se comprometer com a elevação da consciência como parte fundamental da transformação social.
(MARSIGLIA; MARTINS; LAVOURA, 2019, p. 6-7).

Tendo como pano de fundo essa relação e seus desdobramentos, o que implica considerar o objeto aqui estudado enquanto determinado e determinante, o problema de pesquisa deste estudo é: Como a Didática pode contribuir para a formação docente que permita um desenvolvimento pedagógico para além da unilateralidade? Compreende-se que essa problemática está atrelada aos fundamentos teórico-metodológicos da Didática, imbricada aos conhecimentos pedagógicos, sem desconsiderar os aspectos políticos, sociais, econômicos e culturais que a interferem. Assim, questiona-se: Qual a formação que a Didática deve propiciar aos professores? Uma formação desvinculada da realidade e da prática social? Apenas restrita e limitada à sala de aula? Uma formação com que finalidade? Calcada na aparência ou na essência do fenômeno educativo? Enfim, qual Didática?

A partir da história da educação, em distintas teorias pedagógicas percebe-se que a Didática também se transforma. Tomando como referência o materialismo histórico-dialético e centrando-se na pedagogia histórico-crítica, a pesquisa objetivou, centralmente, compreender as contribuições da Didática Crítica para a formação docente. Especificamente, buscou conceituar e categorizar a Didática, entender a relação entre Didática, métodos e técnicas de ensino e formação docente e identificar os fundamentos teórico-metodológicos da Didática.

\section{DELINEAMENTO METODOLÓGICO}

A pesquisa foi desenvolvida por meio de estudos de natureza teórica tomando como recurso a revisão bibliográfica, a partir do contato do pesquisador com o que já foi produzido sobre o tema, uma vez que, segundo Severino (2007), a pesquisa de fonte bibliográfica é desenvolvida com base nos registros decorrentes de pesquisas anteriores. A pesquisa é explicativa quanto aos objetivos, a fim de ir além da descrição e da aparência do objeto estudado, perseguindo seu cerne - pois se a aparência coincidisse com a essência não seria necessária a ciência (MARX, 1985) -, e foi realizada a análise de conteúdo dos materiais disponíveis, de cunho qualitativo.

Ademais, na pesquisa em educação, a função do pesquisador está correlacionada à necessidade de uma concepção dinâmica da realidade social, numa abordagem que considere 
a historicidade, a relação e a interdependência dos fenômenos sociais, pois se não servir aos processos de transformação da essência da realidade social estará servindo aos de sua conservação, uma vez que "Todo ato de pesquisa é um ato político" (ALVES apud LÜDKE; ANDRÉ, 1986 , p. 6), e "pesquisamos a realidade precisamente porque não a conhecemos por inteiro ou porque nunca a conhecemos de modo suficiente" (DEMO, 2008, p. 76).

$\mathrm{Na}$ sistematização do estudo, inicialmente, busca-se uma aproximação com o conceito de Didática, a partir de um conjunto de autores, e sua função na formação de professores. Na sequência, categorizando-a, a Didática é abordada no contexto histórico, apreendendo seus determinantes. A partir deste substrato, adentra-se no debate sobre a Didática Crítica, cujas raízes estão em determinado método, bem como se vislumbra possíveis aspectos em comum com determinada tendência pedagógica presente na história da educação brasileira. Por fim, aponta-se para sua relevância como meio de resistência e luta imprescindível para o desenvolvimento da consciência políticopedagógica do professor, comprometido com a apropriação pelos estudantes de formas mais elaboradas de conhecimentos.

\section{DIDÁTICA: ASPECTOS CONCEITUAIS}

O conceito de Didática varia, em alguma medida, segundo autores que se dedicaram, ou ainda se dedicam, ao estudo do tema.

Para Libâneo (1994), a Didática, principal ramo de estudo da Pedagogia, é a teoria do processo de ensino que une a preparação teórica e prática na formação profissional do professor. Para isso, estuda os objetivos, os conteúdos, os métodos, as conexões entre ensino e aprendizagem, as condições e as formas que vigoram no ensino, os fatores materiais e sociais reais que determinam a relação entre ensino e aprendizagem e o que realmente ocorre na sala de aula.

$\mathrm{Na}$ formação de professores, nos cursos de licenciatura, a Didática integra teoria e prática, tendo como função a efetivação da tarefa de ensinar por meio de um conjunto de operações coordenadas entre si: planejamento, direção do ensino e da aprendizagem e avaliação. Conforme Libâneo (1984, p. 40), os métodos de ensino estão subordinados aos conteúdos,

$$
\begin{aligned}
& {[\ldots] \text { se }} \\
& \text { privilegiar } \\
& \text { a }
\end{aligned}
$$

\begin{abstract}
saber, e de um saber vinculado as realidades sociais, é preciso que os métodos favoreçam a correspondência dos conteúdos com os interesses dos alunos, e que estes possam reconhecer nos conteúdos o auxílio ao seu esforço de compreensão da realidade (prática social).
\end{abstract}

Segundo Libâneo (1994), a Didática sintetiza no seu conteúdo a contribuição de conhecimentos de outras disciplinas que convergem para esclarecer os fatores que determinam $o$ processo de ensino e, concomitantemente, provê conhecimentos específicos necessários para o exercício das atividades docentes. Por isso, para Libâneo (2006), a Didática é uma disciplina integradora que envolve um conjunto de conhecimentos e contribuições oriundas de vários campos, tais como: teoria da educação, teoria do conhecimento, Psicologia, Sociologia, Filosofia, História, entre outras. Isso porque, à explicação do fenômeno educativo contribuem várias áreas do conhecimento, por meio dos conceitos inerentes as suas matrizes epistemológicas, mas é a Pedagogia que o tem como cerne.

Castro (1991) também situa a Didática no campo da teoria do ensino, sendo este seu núcleo central, cuja contribuição ao campo educacional nenhuma outra disciplina poderá cumprir.

Logo, a Didática pode ser entendida como teoria do ensino, cujo fenômeno específico é a aula. Seu objeto de estudo é o processo de ensino-aprendizagem e, para entendê-lo, persegue suportes, vinculando-se aos vários fundamentos: históricos, psicológicos, sociológicos, filosóficos, pedagógicos, antropológicos, econômicos, que se constituem em aportes à educação e formação docente.

Conforme Veiga (1994), a Didática é uma disciplina teórico-prática do curso de formação de professores que tem como objeto de estudo o ensino, ponto de convergência de princípios, pressupostos e teorias provenientes da história, da filosofia, da psicologia, da sociologia da educação. A Didática fornece orientações necessárias para tornar o processo de ensino uma ação intencional e sistemática, não se limitando ao instrumental, as técnicas, pois 
envolve a análise das experiências concretas e dos problemas da prática dos professores.

Rays (2008, p. 12) indica que a Didática não pode ser caracterizada como um processo acabado e esclarece que a dimensão meramente instrumental (técnica), não-crítica da didática escolar, desprovida de senso histórico, contrapõe-se à Didática escolar crítica, a qual "entende que todo ato educativo tem especificidade própria e varia conforme as circunstâncias do contexto histórico em que o mesmo ocorre", ou seja, é uma Didática contextualizada.

Nesse debate, para Boulos (1991, p. 96), a questão fundamental da Didática é o método de ensino "que tem sido obscurecido pela abordagem instrumentalista que se caracteriza pela consideração isolada e desconexa de técnicas e procedimentos de ensino, sem referência a seus fundamentos mais gerais".

De acordo com Rays (2008, p. 15), a função da Didática é

[...] proporcionar meios para o educador realizar mediações entre os conteúdos-meios-fins da educação, com suas respectivas consequências pedagógicas e políticas explicitamente definidas. Lutar e comprometer-se, pois, com a necessidade que a sociedade de classe tem de uma prática pedagógica crítica. Com esse propósito, os conteúdos-meios-fins da ação didática necessitam ser trabalhados de forma não atomizada, isto é, como uma totalidade coerente e coesa, não esquecendo de que a ação didática desenvolve-se dentro de estruturas sociais nas quais os destinos da prática social são amplamente diversificados.

Segundo o autor, o político determina o pedagógico e há uma integração dialética entre político e pedagógico e entre pedagógico e didático. Além disso, para Rays (2008, p. 17), o político trata dos fins e o técnico dos meios, e são, concomitantemente, unidade e diversidade:
“A compreensão teórica e a compreensão prática do fazer didático não ocorrem separadamente, porque constituem um processo único, complexo e dialético." Em decorrência, o ensino se relaciona à intervenção pedagógica, que é política, histórica, cultural, contextualizada. E à Didática se aplica o conceito de plasticidade, no sentido de 0 trabalho docente assumir a capacidade de agir criticamente sobre si, ligado à noção de transformação do ser humano e da sociedade como um todo não atomizado.

Em relação ao método, para a análise do polo epistemológico e de suas relações com a realidade em que ocorre a ação didática, Rays (2008, p. 13) o justifica da seguinte forma: "em razão da contradição ser a causa essencial de todo e qualquer ato educativo e constituir-se no núcleo principal da dialética", uma vez que a prática social transformadora é entendida como uma prática autenticamente revolucionária (CURY, 1985, p. 27 apud RAYS 2008, p. 13-14).

Sobre esse aspecto, nota-se que "há uma relação entre os métodos próprios da ciência que dá suporte à matéria de ensino e os métodos de ensino", uma vez que a "metodologia compreende o estudo dos métodos, e o conjunto dos procedimentos de investigação das diferentes ciências quanto aos seus fundamentos e validade, distinguindo-se das técnicas que são a aplicação específica dos métodos", uma vez que técnicas, recursos ou meios de ensino são seus complementos (LIBÂNEO, 1994, p. 53).

Ademais, conforme Garutti e Oliveira (2012, p. 2818), há a necessidade de distinção entre método científico-filosófico (compreensão do conhecimento entre sujeito-objeto) e método de ensino: "Ambos os métodos pertencem ao campo das ciências, todavia, o caminho que a inteligência percorre para apreender a realidade não é o mesmo que a inteligência percorre para apropriar-se daquilo que já foi descoberto e sistematizado, tornado patrimônio científico e cultural da sociedade". Logo, embora convencionalmente os termos sejam tomados como equivalentes, metodologia científica referese ao método de conhecimento da realidade e metodologia de ensino à Didática, a apresentação do conhecimento da realidade.

Feita essa distinção, é necessário ter em vista que, 
capitalista num momento histórico determinado; portanto como as classes sociais se relacionam vão se materializar em técnicas, processos, métodos, tecnologias, inclusive processos pedagógicos que se realizam através de uma certa relação pedagógica (MARTINS, 1998, p. 23).

Assim, os métodos e as técnicas de ensino estão vinculados à Didática e decorrem de um entendimento político-pedagógico. Ao significar um ordenamento do ensino, implicam recusa à improvisação, pois orientam, teórica e praticamente, o ensino e a aprendizagem, expressando a concepção e execução do processo, o "como se ensina" (ARAújo, 2006).

Para Candau (1987), a Didática é uma reflexão sistemática e que busca alternativas para os problemas da prática pedagógica, tratando sistematicamente do "que fazer" educativo, e que tem como objeto de estudo o processo de ensino-aprendizagem, em sua múltipla dimensão: humana (para que fazer), técnica (o saber fazer) e político-social (porque fazer). Ademais, para a autora, é preciso evitar redução, dissociação ou justaposição destas dimensões. Ao tomar a dimensão humana como eminentemente subjetiva, individualista, afetiva, de relação interpessoal centrada na aquisição de atitudes, mais do que um problema de técnica e ao estar desvinculada das condições sociais, econômicas e políticas, torna-se unilateral e reducionista. Já ao privilegiar a dimensão técnica, toma o processo de ensino-aprendizagem como ação intencional, sistemática, considera-o objetivo e racional, de forma instrumental, mas ao se dar de forma isolada das demais dimensões é vista como supostamente neutra e tecnicista. A dimensão político-social, por sua vez, é inerente ao processo de ensino-aprendizagem, pois impregnada em toda prática pedagógica, embora na análise da Didática ao longo dos tempos, verifique-se, em dado momento, uma afirmação do técnico e o silenciamento do político, pressupondo neutralidade, ou de afirmação do político e negação do técnico, contestando a Didática.

Freitas (1995), por sua vez, entende que a teoria pedagógica, em sentido restrito como Didática - cuja condição de produção é a interdisciplinaridade, a interpenetração de método e conteúdo - relaciona-se com a busca de regularidades subjacentes às metodologias de ensino específicas, ou seja, o que há de comum na prática de ensino das várias disciplinas.

Para o autor, a Didática está subsumida a organização do trabalho pedagógico, que ocorre em dois níveis: na sala de aula, predominantemente; e no projeto políticopedagógico, de uma forma global. Além disso, a organização do trabalho, dentre ela o pedagógico, ocorre dentro "de uma organização social historicamente determinada. [portanto] As formas que essa organização assume, na escola, mantêm ligação com tal tipo de organização social" (FREITAS, 1995, p. 98).

$\mathrm{Na}$ sociedade capitalista, a educação formal tem na escola seu principal lócus de realização, por meio do ensino, de forma intencional, desenvolvida e sistemática, cuja organização expressa uma concepção de educação, uma dada relação desta com a sociedade, uma formação de homem com fins determinados que precisa ser entendida historicamente.

Em sentido amplo, os conhecimentos pedagógicos e a Pedagogia, ciência da e para a educação, devem estar a serviço dos educadores, na responsabilidade social que tem e na solução de problemas concretos (FREITAS, 1995). Isso porque, a Pedagogia estuda o processo educacional em sua totalidade e em sua especificidade, que se refere à identificação dos elementos necessários à constituição da humanidade em cada ser humano, ou seja, dirigese à humanização da geração em desenvolvimento e as formas mais adequadas de atingir essa finalidade (SAVIANI, 1984 apud FREITAS, 1995).

Para Saviani (2007), a pedagogia, entendida como teoria da educação, é uma teoria da prática: a teoria da prática educativa. Conforme Saviani (2000), a questão central da Pedagogia é a questão dos métodos, dos processos, o problema das formas, e não o conteúdo, o saber sistematizado como tal. Mas aquela questão só faz sentido quando viabiliza o domínio de determinados conteúdos, remetendo ao problema da transformação do saber elaborado em saber escolar.

Saviani (2011), ao tratar de suas preocupações sistemáticas com a educação, antecedentes ao desenvolvimento da pedagogia histórico-crítica, explicita que no trabalho 
educativo, além de uma dimensão técnica da educação há também uma dimensão artística. A técnica, "definida como a maneira considerada correta de se executar uma tarefa", caracterizase por um "conjunto de regras extrínsecas que são compendiadas tornando-se suscetíveis de serem apropriadas e aplicadas na atividade prática. Implica, pois, repetitividade". Já a arte, por sua vez, "se refere à realização prática" e "define-se por regras intrínsecas, ditadas pela própria obra a ser feita. Implica, pois, originalidade" (SAVIANI, 2011. p. 204). Esses aspectos, conforme o autor, exigem que o professor encontre a medida adequada de combinação das regras intrínsecas e extrínsecas na realização de sua tarefa.

Assim, enquanto "teoria pedagógica de caráter prático, ou seja, teoria que busca prover respostas às demandas apresentadas pela sociedade à área pedagógica, sobre o desenvolvimento da prática no dia-a-dia da sala de aula, por meio de princípios construídos sobre a realidade concreta dessa prática" a Didática envolve um saber que implica centralmente no como ensinar e da atuação da Pedagogia no processo de como transformar o saber científico em saber escolar (OLIVEIRA, 1993 apud TAVARES, 2008, p. 1).

E, coadunando com esse aspecto, Tavares (2008) entende a Didática como uma concepção de ensino e prática social articulada a outras práticas sociais na formação histórico-social. $\mathrm{O}$ que impõe situá-la no tempo e no espaço, a fim de visualizar seus determinantes.

\section{A DIDÁTICA NAS TEORIAS PEDAGÓGICAS: ASPECTOS HISTÓRICOS}

De acordo com Alves (2005), a organização do trabalho didático não ocorreu sempre da mesma maneira, mas correspondeu ao seu tempo, ou seja, teve formas históricas. Para o autor, a categoria trabalho didático é atrelada a categorias mais centrais, como trabalho e organização técnica do trabalho, educação e escola. Esta aproximação é extremante pertinente e necessária, porque as transformações do trabalho na sociedade interferem nas relações que são estabelecidas em seu interior, como a educação. Logo, cada época produz sua relação educativa.

Alves (2005) identifica na Didática Magna de Comênio, na proposta e nos procedimentos de "ensinar tudo a todos", a centralidade da categoria trabalho didático e sua base material, a produção manufatureira, que fundamentam a forma de organização da escola moderna, uma instituição educacional especializada, organizada e sistemática, com uma função precisa, cuja gênese está na transição entre a forma individual e coletiva de ensino, entre os séculos XV e XVI.

Até à época medieval, a relação educativa era, sobretudo, uma relação não-sistemática entre um educador e um educando. A educação sistemática, antes da modernidade, equiparavase a outras atividades de natureza artesanal, sendo sujeitos do processo o educador, designado de mestre ou preceptor, em relação ao educando, o discípulo. Na sociedade feudal, o mestre artesão expressava o trabalhador que detinha o domínio pleno, no âmbito teórico e prático, da atividade a qual se dedicava. $\mathrm{E}$, de forma mediada na educação, o mestre dominava todas as etapas e operações da atividade de ensino, de formação humanística (ALVES, 2005).

Sob a perspectiva da manufatura, Comênio pensou o trabalho didático, a divisão do ensino em etapas, graus e níveis, estabeleceu áreas de conhecimentos que compunham o plano de estudos e desenvolveu a tecnologia fundamental: o manual didático, enquanto instrumento de trabalho para a transmissão do conhecimento. E esses elementos, associados à instituição que emergiria - "oficina de homens" , espaço sede para o desenvolvimento da relação educativa, também produziram um profissional especializado. Assim, segundo Alves (2008, p. 106), Comênio delineou a organização do trabalho didático à escola moderna e sua Didática "constitui uma proposta de educação para a sociedade; visa atender necessidades sociais e mobiliza, para a sua consecução, os recursos mais avançados produzidos pela humanidade em seu tempo".

Conforme Saviani (2007, p. 100-101), "Comênio procurou equacionar a questão metodológica da pedagogia. Por esse caminho buscou construir um sistema pedagógico articulado em que a consideração dos fins da educação constituía a base para a definição dos meios, compendiados na didática como a arte de ensinar tudo a todos", mas, foi "com Herbart que os dois aspectos da tradição pedagógica foram identificados como distintos, sendo unificados num sistema coerente: os fins da educação, que a pedagogia deve elaborar a partir da ética; e os meios educacionais, que a mesma pedagogia elabora com base na psicologia". O autor se refere ao fato de que, 
Desde a Grécia, delineouse uma dupla referência para o conceito de pedagogia. De um lado, desenvolveu-se uma reflexão estreitamente ligada à filosofia, elaborada em função da finalidade ética que guia a atividade educativa. De outro lado, o sentido empírico e prático inerente à paidéia, entendida como a formação da criança para a vida, reforçou o aspecto metodológico presente já no sentido etimológico da pedagogia como meio, caminho: a condução da criança. A partir do século XVII esses dois aspectos tenderam a se unificar como o demonstra o esforço realizado por Comênio (SAVIANI, 2007, p. 100).

Alves (2005) depreende, a partir disso, que cada época produz sua relação educativa: a) uma forma de educador e uma forma de educando; b) determinados recursos didáticos, envolvendo procedimentos a serem adotados e conteúdos para o processo de transmissão do conhecimento; e c) um espaço físico. Em decorrência, compreende que a educação, e propriamente o ato de ensinar, é histórica, pois visa atender necessidades sociais postas pelo tempo e, para isso, mobiliza o que é necessário para sua realização.

Ao buscar identificar as propostas pedagógicas presentes na educação e os enfoques do papel da Didática, bem como os fundamentos teóricos e metodológicos, Veiga (1994; 2004) releva aspectos sociais, econômicos, políticos e educacionais, na retrospectiva histórica da Didática no Brasil. E que, de certa forma, explicitam no contexto do país, em várias épocas, os aspectos da relação educativa apontados por Alves (2005). Desta forma, na sequência, a Didática será analisada em seu percurso histórico, abordada na história da educação no Brasil, por meio das teorias pedagógicas.

$\mathrm{Na}$ abordagem da escola tradicional, no contexto colonial e de economia agro- exportadora, sob a forma da vertente religiosa (1549-1759), o trabalho dos jesuítas no campo educacional seguia o plano de instrução baseado na Ratio Studiorum (razão de estudo), com a formação do homem universal, humanista e cristão/cultura geral e enciclopédica, enquanto os indígenas eram catequizados. Os pressupostos didáticos eram: o estudo privado; o mestre prescrevia a matéria e o horário; aulas expositivas; repetições para decorar; desafios estimulando a competição; exames orais e escritos; centrado no caráter formal com base no intelecto e marcado pela visão essencialista do homem - criação divina e imutável. Na vertente leiga (1759-1930), com a derrubada do plano de instrução dos jesuítas e sua expulsão por Marquês de Pombal, são instauradas aulas-régias, com professores leigos e, a partir de 1870, é suprimido o caráter religioso da educação escolar. O Estado assume a laicidade do ensino, mas mantém o caráter essencialista de homem, de natureza racional (VEIGA, 1994; 2004).

Segundo a autora, a teoria pedagógica tradicional: enfatiza o ensino humanístico de cultura geral; é centrada no professor, autoridade inquestionável, que transmite verdades enciclopédicas; a relação é hierárquica e o estudante é tomado como ser receptivo e passivo; o método de ensino é concebido como um processo universal e lógico, que segue a organização em etapas metodológicas, os passos formais de Herbart (VEIGA, 1994; 2004).

Saviani (2003) explicita que esses passos metodológicos se referem: 1) A preparação dos estudantes, cuja iniciativa é do professor, recorda a lição anterior, o já conhecido; 2) A apresentação de novos conhecimentos por parte do professor põe diante do estudante um novo conhecimento que lhe cabe assimilar; 3) A assimilação de conteúdos transmitidos pelo professor ocorre por comparação com conhecimentos anteriores, o novo é assimilado a partir do velho, identifica e destaca o diferente entre elementos já conhecidos; 4) A generalização é a identificação de todos os fenômenos correspondentes ao conhecimento adquirido, de todos os elementos que integram a mesma classe de fenômeno; e 5) A aplicação coincide com as "lições de casa", cujo exercício demonstra se aprendeu, se assimilou ou não o conhecimento (SAVIANI, 2003). Ao ensino corresponde uma aprendizagem. A preparação da lição seguinte começa recapitulando a anterior, pela correção da lição de casa, dos 
exercícios, que permitem verificar se os conteúdos foram assimilados ou se devem ser reforçados com novos exercícios, em que a aprendizagem se prolongue um pouco mais até ser efetivada, e passar para um novo conhecimento.

Para Saviani (2003), esta forma de ensino está articulada ao produto da ciência, a transmitir os conhecimentos obtidos pela ciência que já estão sistematizados e incorporados ao acervo cultural da humanidade. Centra-se no professor, o adulto, que domina os conteúdos logicamente estruturados e organizados e estrutura-se por meio do método pedagógico que é expositivo, cuja matriz teórica pode ser identificada nos passos formais de Herbart, que correspondem ao esquema do método científico indutivo (a observação, a generalização e confirmação são momentos fundamentais), tal como formulado por Bacon no interior do movimento filosófico do empirismo, base de desenvolvimento da ciência moderna.

Além disso, conforme Saviani (2007), as diversas modalidades de pedagogia tradicional na vertente religiosa ou leiga priorizam a teoria sobre a prática e dissolvem a prática na teoria. Sua preocupação se centra nas teorias do ensino, em como ensinar e, em termos históricos, foi dominante até o final do século XIX. Pautando-se na centralidade da instrução, a escola é concebida como uma agência centrada no professor, cuja tarefa é transmitir os conhecimentos acumulados pela humanidade conforme uma gradação lógica e aos alunos caberia assimilar os conteúdos transmitidos. Para a tendência tradicional, "a prática era determinada pela teoria que a moldava fornecendo-lhe tanto o conteúdo como a forma de transmissão pelo professor, com a consequente assimilação pelo aluno", logo, "pondo a ênfase na teoria, reforça o papel do professor, entendido como aquele que, detendo os conhecimentos elaborados, portanto, o saber teoricamente fundamentado, tem a responsabilidade de ensiná-los aos alunos mediante procedimentos adequados que configuram os métodos de ensino" (SAVIANI, 2007, p. 104-105).

Portanto, a Didática, na tendência pedagógica tradicional, é entendida como conjunto de regras, dissociada do social e do político, e não tem como ponto de partida os problemas do cotidiano da sala de aula. A prática é a aplicação da teoria e a disciplina é a forma de garantir a atenção, o silêncio e a ordem (VEIGA, 1994, 2004).

A autora identifica que o movimento de renovação da didática tradicional, com a escola nova (1930-1945), ocorre num contexto educacional de confronto entre a concepção humanista tradicional (católica) e a humanista moderna (os pioneiros), baseada: na valorização do estudante, ser ativo e potencial; o conteúdo é reduzido à forma; no relacionamento positivo e amigável entre estudante e professor para atingir um clima de harmonia e interação; acentua o caráter prático e útil; difunde centros de interesse, método de projetos, estudo dirigido; e o ensino é tomado como um processo de pesquisa.

Segundo Saviani (2003), a pedagogia nova tem como ponto inicial: 1) A atividade, que é de iniciativa dos estudantes, suscitando determinado problema; 2) O problema, como um obstáculo que interrompe a atividade dos estudantes e precisa ser resolvido, e provocaria o passo seguinte; 3 ) O levantamento, a coleta de dados, a partir dos quais seria realizado o passo subsequente; 4) A formulação da hipótese, explicativa do problema questionado, empreendendo professor e estudantes; e 5) A experimentação, que permitiria confirmar ou rejeitar as hipóteses formuladas. Para o autor, esses passos seguem o processo de descoberta de novos conhecimentos do método científico, do modelo experimentalista, ao qual se filiava Dewey. O ensino se articula ao processo de desenvolvimento da ciência, a pesquisa, privilegiando o processo de obtenção dos conhecimentos, as motivações e interesses da criança em desenvolver procedimentos que a levem a posse de conhecimentos que respondam suas dúvidas e questionamentos.

De acordo com Saviani (2007), no século XX há o deslocamento para essa tendência que veio a se tornar predominante, ou seja, as diferentes modalidades da pedagogia nova, que subordinam a teoria à prática e dissolvem a teoria na prática. Sua ênfase é posta nas teorias da aprendizagem, em como aprender. Pautandose na centralidade do educando, a escola é concebida como um "espaço aberto à iniciativa dos alunos que, interagindo entre si e com o professor, realizam a própria aprendizagem, construindo seus conhecimentos. Ao professor cabe 0 papel de acompanhar os alunos auxiliando-os em seu próprio processo de aprendizagem" (SAVIANI, 2007, p. 104). Com o 
primado da prática sobre a teoria, a teoria se subordina a prática, renunciando a qualquer tentativa de orientá-la. Desta forma, a tendência renovadora, pondo a ênfase na prática, reforça o papel do aluno, que só pode aprender na atividade prática, "tendo a iniciativa da ação, expressa seu interesse quanto àquilo que é valioso aprender e percorre, com o auxílio do professor, os passos de sua educação que configuram o método de aprendizagem pelo qual ele, aluno, constrói os próprios conhecimentos" (SAVIANI, 2007, p. 105).

Para Saviani (2003), esta maneira de entender a educação, que tem a visão de homem centrada na existência, na vida, na atividade, move o eixo da questão pedagógica: do intelecto para o sentimento, do lógico para o psicológico, dos conteúdos para os métodos, do professor para o aluno, do esforço para o interesse, da disciplina para a espontaneidade, do diretivismo para o não diretivismo, da quantidade para qualidade, da ciência lógica para a experimentação e do aprender para o aprender a aprender.

Duarte (2008), ao tratar do lema do "aprender a aprender", que também é um aprender fazendo, focaliza alguns posicionamentos valorativos presentes nesse lema, quais sejam: são mais desejáveis as aprendizagens que o indivíduo realiza por si mesmo; importa mais o método de construção do conhecimento do que o conhecimento já produzido socialmente; a atividade do aluno, para ser educativa, deve ser impulsionada e dirigida pelos interesses e necessidades da própria criança; e a educação deve preparar os indivíduos para acompanharem a sociedade em acelerado processo de mudança. Ou seja, trata-se de uma pedagogia que relativiza o conhecimento sistematizado pela humanidade e desvaloriza o papel do professor e da escola (DUARTE, 2000a apud $\mathrm{FACCl}, 2011$ ). Além disso, sintetiza-o como "uma concepção educacional voltada para a formação, nos indivíduos, da disposição para uma constante e infatigável adaptação à sociedade regida pelo capital" (DUARTE, 2008, p. 11).

De acordo com Saviani (2003, p. 63), a pedagogia baseada no movimento escolanovista entende, assim como a pedagogia tradicional, "a escola como 'redentora da humanidade'. Acreditavam que era possível modificar a sociedade por meio da educação. Nesse sentido, podemos afirmar que ambas são ingênuas e idealistas". Ademais, para Saviani (2007), a solução do dilema da relação teoria-prática, impossível na pedagogia tradicional e nova, demanda outra formulação teórica que supere a posição excludente e consiga articular teoria e prática.

Conforme Veiga (1994; 2004), a característica mais relevante do escolanovismo é a valorização da criança, cuja liberdade, iniciativa, autonomia e interesse devem ser respeitados. A Didática é concebida, então, na tendência pedagógica escolanovista, como "conjunto de ideias e métodos, privilegiando a dimensão técnica do processo de ensino, fundamentada nos pressupostos psicológicos, psicopedagógicos e experimentais" (VEIGA, 1994, p. 52).

Para Saviani (2003, p. 66), “a crítica escolanovista atingiu não tanto o método tradicional, mas a forma como esse método se cristalizou na prática pedagógica, tornando-se mecânico, repetitivo, desvinculado das razões e finalidades que o justificavam". E aponta que a proposta metodológica da Escola Nova pode ser avaliada também por suas consequências na prática pedagógica, pelo efeito de, por sua vez, aprimorar a educação das elites e esvaziar ainda mais a educação das massas, contribuir para o afrouxamento da disciplina e pela secundarização da transmissão de conhecimentos, para desorganizar o ensino nas escolas, rebaixando o nível da educação destinada às camadas populares.

Veiga $(1994,2004)$ explicita que com o predomínio de novas ideias e lutas ideológicas (1945-1960), entre escola particular e escola pública, é articulada uma Didática que se inspira no liberalismo e no pragmatismo afirmando a predominância dos processos metodológicos em detrimento da aquisição dos conhecimentos. A crise do escolanovismo articula a tendência tecnicista, assumida pelo grupo militar pós 1964 e os descaminhos da didática. Essa tendência é calcada nos pressupostos da neutralidade científica, decorrente da racionalidade, eficiência e produtividade.

Além disso, há uma fragmentação do processo: especialistas projetam, professores executam. Conforme Saviani (2003, p. 13), há também uma centralização, pois no processo de concepção, de planejamento do ensino, a coordenação e controle ficam a cargo de especialistas "supostamente habilitados, neutros, objetivos, imparciais". Com isso, cresceu nas escolas um processo de burocratização, com instruções detalhadas de como proceder nas 
tarefas e fragmentação que inviabilizava a realização do trabalho pedagógico, pois o que importava era o fazer, sendo a prática de ensino tomada como treinamento. Assim, se antes eram o professor, depois o estudante, aqui o eixo do processo de ensino são as formas, a organização racional dos meios, ou seja, importa o aprender a fazer.

Há, ainda, uma ruptura com a perspectiva psicológica por meio da implantação da tecnologia educacional, em prol da eficácia e eficiência do processo de ensino. A organização racional do processo tem a Didática como estratégia para alcançar os produtos previstos, por meio de planos elaborados segundo metas prefixadas, ou seja, o planejamento e as estratégias predominam. $O$ ensino é mecanizado e alicerçado na tecnologia educacional, com elaboração de materiais instrucionais (livros descartáveis), sendo a avaliação classificatória. A teoria é comandada pela ciência e a prática é a aplicação da teoria assegurada pela tecnologia educacional: os meios são o centro do processo (VEIGA, 1994; 2004).

Para a autora, a partir de 1974, com a abertura gradual do regime ditatorial e a crítica à educação tecnicista, a didática acompanha o discurso das teorias crítico-reprodutivistas: busca desmistificar e evidenciar o conteúdo ideológico do ensino; entende a educação no contexto social, mas ao negar a especificidade didáticopedagógica/sua dimensão técnica - ainda que denuncie a falsa neutralidade do técnico - e privilegiar sua dimensão política, prevalece o formalismo social e deixa de lado os vínculos da relação professor-estudante.

Saviani (2000; 2003) explicita que embora as teorias crítico-reprodutivistas sejam capazes de fazer a crítica ao existente e de explicar os mecanismos de funcionamento da escola, não contêm uma proposta pedagógica, uma vez que consideram que a escola, pelo seu caráter reprodutivista, não poderia ser diferente do que é e, nesse limite, a prática pedagógica do professor situa-se no âmbito da violência simbólica, da inculcação ideológica e/ou da reprodução das relações de produção.

Isso porque, conforme o autor, se toda pedagogia pode ser considerada teoria da educação, nem toda teoria da educação é pedagogia, pois: estrutura a partir e em função da prática educativa. A pedagogia, como teoria da educação, busca equacionar, de alguma maneira, o problema da relação educador-educando, de modo geral, ou, no caso específico da escola, a relação professor-aluno, orientando o processo de ensino e aprendizagem. Assim, não se constituem como pedagogia aquelas teorias que analisam a educação sem ter como objetivo formular diretrizes que orientem a atividade educativa (SAVIANI, 2007, p. 102).

Este é o caso das teorias críticoreprodutivistas, ou seja, não são teorias pedagógicas, uma vez que analisam a educação pelo aspecto de sua relação com a sociedade, mas não objetivam elaborar diretrizes que orientem a atividade educativa (SAVIANI, 2012).

No contexto da abertura democrática, nos anos 1980, emerge a necessidade de constituição de pedagogias contra-hegemônicas, "que em lugar de servir aos interesses dominantes se articulassem com os interesses dominados" (SAVIANI, 2010, p. 402 apud MARSIGLIA, 2011a). Estas pedagogias, conforme Saviani (2010 apud MARSIGLIA, 2011a), podem ser agrupadas em duas grandes tendências: 1 ) centrada no saber popular e na autonomia, inspirada nas ideias de Paulo Freire (pedagogias da "educação popular") e na tradição anarquista (pedagogias da prática); 2) a pedagogia críticosocial dos conteúdos (José Carlos Libâneo) e a pedagogia histórico-crítica, inspirada no marxismo, mas com diferentes interpretações.

[...] uns mantinham como referência a visão liberal, interpretando o marxismo apenas pelo ângulo da crítica às desigualdades sociais e da busca de igualdade de acesso e permanência nas escolas organizadas com o mesmo padrão de qualidade; outros se empenhavam em compreender os fundamentos do 
materialismo histórico, buscando articular a educação com uma concepção que se contrapunha à visão liberal (SAVIANI, 2010, p. 415 apud MARSIGLIA, 2011a, p. 1).

Conforme Marsiglia (2011a), as pedagogias contra-hegemônicas não conseguiram alcançar os resultados esperados e a hegemonia do neoliberalismo e pós-modernismo, na década de 1990, fez refluir à adesão a essas pedagogias. Mesmo nesse contexto adverso, muitos educadores continuaram a trabalhar na perspectiva da pedagogia histórico-crítica. A pedagogia crítico-social dos conteúdos, não foi retomada de forma explícita por Libâneo a partir da década de 1990 (SAVIANI, 2010 apud MARSIGLIA, 2011a), porém,

[...] suas discussões no campo da didática demonstram que $\mathrm{o}$ Professor Libâneo mantém aquilo que anteriormente mencionamos sobre interpretações do marxismo somente para a crítica às desigualdades. Sua concepção didática é de que é possível alinhavar a psicologia históricocultural com os princípios do "aprender a aprender" (MARSIGLIA, 2011a, p. 3).

Destarte, "contrariamente à posição defendida por Libâneo, concordamos com a posição explicitada por Duarte em seu artigo 'Porque é necessária uma análise crítica marxista do construtivismo' (2008) no sentido de que os princípios pedagógicos sintetizados no lema 'aprender a aprender' não são incorporáveis à teoria pedagógica marxista" (MARSIGLIA, 2011a, p. 4).

Por conseguinte, em suma, nos anos 1980, no contexto de democratização da sociedade e de compromisso por sua transformação, a Didática é questionada e iniciase o movimento em torno de sua revisão, partindo da concepção crítica da educação: de homem como ser concreto; de educação identificada com o processo de hominização e comprometida com os interesses das camadas economicamente desfavorecidas; e de escola como espaço de negação da dominação. Essa preocupação, da concepção dialética na filosofia da educação, vai além do empenho individual de sistematização, isolado, e se torna objeto de um esforço coletivo (SAVIANI, 1984 apud VEIGA, 2004). Nesse escopo, a emergência da pedagogia histórico-crítica se insere na tentativa de superar tanto os limites das Pedagogias não-críticas (Tradicional, Escolanovista e Tecnicista) como os da Pedagogia crítico-reprodutivista (SAVIANI, 2003).

A Didática, então, numa concepção crítica, auxilia o processo de politização do futuro professor: clarifica o papel socioeconômico; vai além de métodos e técnicas; trabalha relações; conteúdo e forma; técnica e política; ensino e pesquisa. Sua contribuição está em clarificar a função política da educação, da escola e do ensino.

[...] o enfoque da Didática, de acordo com os fundamentos da Pedagogia Crítica, deverá trabalhar no sentido de ir além dos métodos $\mathrm{e}$ técnicas, procurando associar escola-sociedade, teoria-prática, bem como desenvolver uma alternativa que supere a relação dicotômica entre a pedagogia e a política, dotadas de especificidades próprias, porém inseparáveis por se constituírem em modalidades específicas de uma prática, a prática social. Saviani reafirma isto, observando que 'Cumpre, portanto, não confundi-los, o que redundaria em dissolver uma na outra (a dissolução da educação na política configuraria o politicismo pedagógico do mesmo modo que a dissolução da política na educação implicaria o viés do pedagogismo político)'. (SAVIANI, 1983, p. 88 apud VEIGA, 1994, p. 67-68).

A partir destes aspectos, pode-se dizer que a Didática Crítica emerge no contexto de constituição de pedagogias contra-hegemônicas, 
pedagogias críticas, mas não encontra, propriamente, respaldo em uma pedagogia à qual corresponderia uma reflexão radical, rigorosa e de conjunto dos problemas da prática educativa. Todavia, essa compreensão não descarta, de antemão, possíveis aspectos que a relacionem à determinada teoria pedagógica. Ademais (e problematicamente), a história explicita que o termo Didática Crítica acabou sendo utilizado tanto pelo movimento em prol da educação pública, nos anos, 1980, como, posteriormente, pelos "pós-críticos" perpassando, portanto, distintas perspectivas teóricas, tanto com viés emancipador, como diametralmente oposto ao caráter instrumental da didática em busca do seu fundamento, até de cunho reflexivo.

Nos anos 1990, com o projeto neoliberal, a Didática ganha enfoque "modernizador" ligado à concepção da Pedagogia das/por competências e a avaliação dos resultados. Restrita a um conjunto de informações técnicas para o exercício da docência e limitada à preparação prática, em detrimento a teoria e ao conhecimento dos fundamentos do fazer, deixa à margem a relação da escola com a realidade social.

Nesse âmbito, por exemplo, segundo Faria (2012), Candau aponta que a contribuição da Didática Crítica seria mais efetiva pelos caminhos de uma didática crítico-intercultural. $\mathrm{E}$ passa a dialogar com ideias pós-modernas, numa autocrítica, e a questionar os desafios da escola que no processo de ensino-aprendizagem não poderia ignorar questões como preconceito, discriminação, gênero, raça, etnia, diversidade, igualdade, diferença, violência, cultura, entre outros. A "ressignificação" da didática passaria, então, pela aproximação com os estudos da interculturalidade e com as teorias pósmodernas, como o multiculturalismo, num viés incompatível com a concepção crítica de educação.

Em que pese à importância destas questões sociais, é preciso ter em vista o que é central e o que é secundário na educação formal. Conforme Faria (2012), há, na esteira do impacto e/ou rebatimento do ideário pós-moderno na produção didática, junto ao retrocesso que a permeia, a retirada de seu compromisso central com o ensino, ao mesmo tempo em que se evidenciam o desprezo pelas questões da Pedagogia e da Didática.
Portanto, ao considerar os aspectos abordados anteriormente, depreende-se que a Didática se categoriza ao longo dos tempos na formação histórico-social brasileira e está em estreita relação com esta. Além disso, revela uma materialidade expressa em âmbito teóricoprático, em como se pensa e realiza o processo de ensino-aprendizagem, vinculada a teorias pedagógicas.

\section{Didática Crítica e Pedagogia Histórico-Crítica: aspectos relevantes e desafios}

Para Veiga (2004; 1994, p. 75), "a

Didática Crítica busca superar o intelectualismo formal do enfoque tradicional, evitar os efeitos do espontaneísmo escolanovista, combater a orientação desmobilizadora do tecnicismo e recuperar as tarefas especificamente pedagógicas, desprestigiadas a partir do discurso reprodutivista.". Ou seja, busca superar dicotomias, reducionismos e formalismos evidenciados nas teorias pedagógicas.

Busca, também, compreender e analisar a realidade social na qual a escola está inserida, pois entende a contradição da educação numa sociedade de classes, enquanto determinada e determinante, uma vez que concebe a escola como parte integrante da sociedade, instância de difusão do conhecimento, cuja função primordial é o ensino, a unidade entre teoria e prática.

Essa unidade deve ser o núcleo articulador da formação docente e constitui uma relação, simultânea e recíproca, de autonomia e dependência, entre esses dois componentes indissolúveis da práxis. A partir da contribuição de Vázquez (1968 apud SAVIANI, 2000), a práxis é um conceito sintético que articula teoria e prática - aspectos distintos, mas inseparáveis, "definindo-se e caracterizando-se sempre um em relação ao outro" (SAVIANI, 2007, p. 108).

A Didática Crítica centra-se na formação do ser humano e a relação pedagógica assenta-se na autonomia e na reciprocidade dos sujeitos que fazem parte do processo formativo. O estudante, um ser concreto, situado historicamente, traz um saber que lhe é próprio, que precisa ser valorizado e reelaborado para de forma consciente gerar mudanças. O professor pode tornar possível a ruptura entre a experiência pouco elaborada e dispersa dos estudantes em direção aos conteúdos culturais universais que são permanentemente reavaliados diante da sociedade (VEIGA, 1994; 2004). 
A Didática Crítica está compromissada com "o ensino voltado para os interesses das classes populares, com a transformação das relações de opressão e dominação e com a democratização da escola pública; com o entendimento da sala de aula como espaço de progressão próprio do saber didático-prático" (TAVARES, 2008, p. 1).

Vale explicitar que, a Didática que se proponha crítica não pode prescindir que, na análise de Marx, a crítica: opõe-se a uma realidade concreta; é materialista, conduz-se sobre o real, em determinado momento histórico concreto; está inserida numa totalidade histórica e social; deve explicitar a relação entre os valores educativos e as condições materiais subjacentes aos mesmos e contribuir para destruir suas bases; deve situar a educação no contexto de produção e reprodução capitalista, explicitando sua função nesse processo; e precisa localizar as tendências (no campo da educação) existentes na sociedade, buscando a solução para antíteses nelas possíveis (ENGUITA, 1985 apud FREITAS, 1995).

Portanto, verifica-se que há uma relação entre Didática Crítica e determinada tendência pedagógica na educação brasileira que tem com ponto de referência 1979, momento em que se estruturou a pedagogia histórico-crítica. Esta concepção, conforme Saviani (2000), procurava reter o caráter crítico de articulação com as condicionantes sociais que a visão reprodutivista possui, vinculado, porém, à dimensão histórica que o reprodutivismo perde de vista, uma vez que tem dificuldade em dar conta das contradições, pois se explicitam no movimento histórico. É, pois, "Histórico: Porque nesta perspectiva a educação também interfere sobre a sociedade, podendo contribuir para a sua transformação. Crítica: Por ter consciência da determinação exercida pela sociedade sobre a educação" (SAVIANI apud GASPARIN; PETENUCCI, 2007, p. 04).

Nesse sentido, compreende-se que ambas referem-se à dimensão histórica e o caráter de articulação com os determinantes sociais da educação, no âmbito das concepções críticas da educação.

A pedagogia histórico-crítica, denominação adotada em 1984, é "o empenho em compreender a questão educacional a partir do desenvolvimento histórico objetivo" e a concepção pressuposta nela "é o materialismo histórico, ou seja, a compreensão da história a partir do desenvolvimento material, da determinação das condições materiais da existência humana" (SAVIANI, 2000, p. 102). Trata-se, pois, conforme reiterado por Saviani em diversas oportunidades e explicitado por Duarte (1994 apud SAVIANI, 2011), de um esforço coletivo que vem se desenvolvendo, que diz respeito à elaboração teórica e ao enfrentamento dos problemas postos pela prática no campo educacional.

Uma proposta didático-pedagógica, na formação de professores, assentada nesse método, compreende o movimento que constitui e transforma o objeto, a contradição, ou seja, uma abordagem dialética, do materialismo histórico-dialético, instrumento de análise para compreender e transformar a realidade. A dialética é teoria do movimento da realidade, teoria que busca captar o movimento objetivo do processo histórico (SAVIANI, 2000).

Conforme Konder (2008, p.7-8) a dialética "[...] é modo de pensarmos as contradições da realidade, o modo de compreendermos a realidade como essencialmente contraditória e em permanente transformação". Seu fundamento está exposto por Marx na 11으 tese sobre Feuerbach: "Os filósofos têm se limitado a interpretar o mundo; trata-se, no entanto, de transformá-lo" (MARX apud KONDER, 2008, p. 85).

A pedagogia histórico-crítica é uma teoria pedagógica e

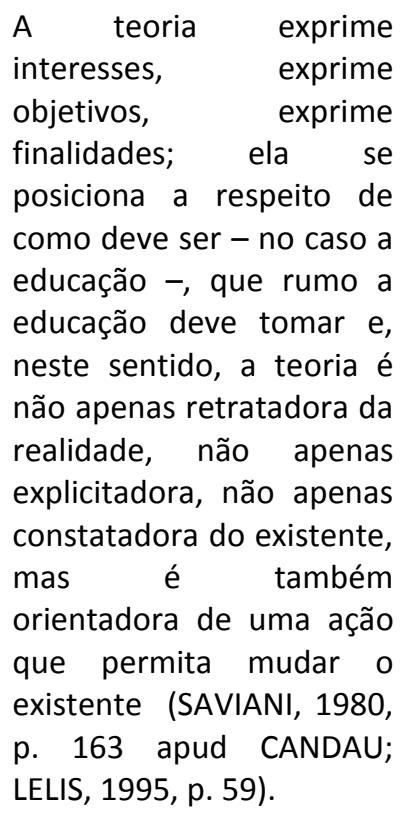

Uma pedagogia articulada com os interesses populares valorizará, pois, a escola; não será indiferente ao que ocorre 
em seu interior; estará empenhada em que a escola funcione bem; portanto, estará interessada em métodos de ensino eficazes. Tais métodos situar-se-ão para além dos métodos tradicionais e novos, superando por incorporação as contribuições de uns e de outros. Serão métodos que estimularão a atividade e iniciativa dos alunos sem abrir mão, porém, da iniciativa do professor; favorecerão o diálogo dos alunos entre si e com o professor, mas sem deixar de valorizar o diálogo com a cultura acumulada historicamente; levarão em conta os interesses dos alunos, os ritmos de aprendizagem e o desenvolvimento psicológico, mas sem perder de vista a sistematização lógica dos conhecimentos, sua ordenação e gradação para efeitos do processo de transmissãoassimilação dos conteúdos cognitivos (SAVIANI, 2008, p. 69).

Saviani (2000, p. 89) compreende que, enquanto referência para pensar as demais formas de educação na atual sociedade, "a escola tem o papel de possibilitar o acesso das novas gerações ao mundo do saber sistematizado, do saber metódico, científico. Ela necessita organizar processos, descobrir formas adequadas a essa finalidade". Isso implica método e formas de organizar o conjunto das atividades que ocorrem no espaço e tempo escolar, seu currículo. Assim, em relação à Didática, para a pedagogia históricocrítica, deve-se ter em vista que,

$$
\begin{aligned}
& \text { [...] a educação é } \\
& \text { entendida como mediação } \\
& \text { no seio da prática social } \\
& \text { global. A prática social se } \\
& \text { põe, portanto como ponto } \\
& \text { de partida e o ponto de } \\
& \text { chegada da prática }
\end{aligned}
$$

educativa. Daí decorre um método pedagógico que parte da prática social em que professor e aluno se encontram igualmente inseridos ocupando, porém posições distintas, condição para que travem uma relação fecunda na compreensão encaminhamento da solução dos problemas postos pela prática social (problematização), [...] dispor os instrumentos teóricos e práticos para sua compreensão e solução (instrumentação) e viabilizar sua incorporação como elementos integrantes da própria vida dos alunos (catarse) (SAVIANI, 2008, p. 422). ${ }^{1}$

Esse método pedagógico, conforme Saviani (2000; 2003), tem como ponto de partida a prática social, comum ao professor e aos estudantes, porém ambos se posicionam diferentemente, enquanto agentes sociais diferenciados e pedagogicamente também há uma diferença entre eles, pois estão em níveis diferentes de compreensão de conhecimento e de experiência da prática social.

A problematização consiste na identificação dos principais problemas postos pela prática social, detectando que questões precisam ser resolvidas na prática social e que conhecimento é preciso dominar.

Para tanto, será necessária a instrumentalização, a apropriação dos instrumentos teóricos e práticos necessários para resolver o problema, sendo que esses instrumentos são produzidos socialmente e preservados historicamente, e sua apropriação pelos estudantes depende direta ou indiretamente (indicando os meios pelos quais venha a se efetivar) da transmissão por parte do professor. Isto é, as camadas populares devem apropriar-se das ferramentas culturais

\footnotetext{
${ }^{1}$ Conforme Saviani (2015, p. 26), a mediação "é uma categoria central da dialética que, em articulação com a 'ação recíproca', compõe com a 'totalidade' e a 'contradição', o arcabouço categorial básico da concepção dialética da realidade e do conhecimento", a qual é abordada na pedagogia histórico-crítica em intermediação com a psicologia histórico-cultural.
} 
necessárias à luta social que travam para se libertar das condições de exploração que vivem (SAVIANI, 2003).

A catarse, por sua vez, constitui expressão elaborada da nova forma de entendimento da prática social a que ascendeu o educando. Conforme Saviani (2012, p. 82) a acepção gramsciana do termo catarse adequadamente exprime "o momento de efetiva incorporação dos instrumentos culturais, transformados, pela mediação do trabalho pedagógico, em elementos ativos de transformação social".

O ponto de chegada é a própria prática social, momento em que os estudantes ascendem ao nível que supostamente o professor se encontrava no ponto de partida, cuja compreensão deste se torna mais orgânica, ou seja, momento em que os estudantes têm a capacidade de expressar uma compreensão da prática em termos elaborados quando 0 professor já detinha.

Trata-se de um movimento que vai da visão caótica do todo, da compreensão superficial e de uma síntese precária, a uma rica totalidade de determinações e de relações numerosas, as abstrações e determinações mais simples, logo, a passagem da síncrese à síntese, pela mediação da análise, elemento central na teoria dialética da educação formulada (SAVIANI, 2003; 2000).

Por conseguinte, o trabalho educativo é o ato de produzir, direta e intencionalmente, em cada indivíduo singular, a humanidade que é produzida histórica e coletivamente pelo conjunto dos homens (SAVIANI, 2000). ${ }^{2}$ O objeto da educação se refere, então, concomitantemente: a) à identificação dos elementos culturais que precisam ser assimilados pelos indivíduos da espécie humana para que se tornem humanos. Trata-se de distinguir entre $o$ essencial e o acidental, o principal e o secundário, o fundamental e o acessório. Nesse âmbito, o clássico pode se constituir num critério útil para a seleção dos conteúdos do trabalho pedagógico, pois se refere aquilo que se firmou como fundamental, como essencial; b) à descoberta

\footnotetext{
2 Este entendimento decorre de que o ser humano, enquanto sujeito histórico, se constitui pelas relações sociais por meio do trabalho. A realidade humana é, portanto, construída pelos próprios homens (SAVIANI, 2000) e há a necessidade de "mediação entre o processo histórico de formação do gênero humano e o processo de formação de cada indivíduo como ser humano", pois "no caso do ser humano a relação entre os indivíduos e a história social é mediatizada pela apropriação das objetivações produzidas historicamente" (DUARTE, 2008, p. 31).
}

das formas mais adequadas para atingir esse objetivo, a organização dos meios (conteúdos, espaço, tempo e procedimentos) para o desenvolvimento do trabalho pedagógico (SAVIANI, 2000).

Martins (2011, p. 56), ao tratar da transmissão do conhecimento do ponto de vista gnosiológico e psicológico, entende que é "direito inalienável de todos os indivíduos o seu máximo desenvolvimento, cabendo à educação escolar trabalhar a serviço deste" para garantir a qualidade de ser humano, uma vez que compete a esta instituição ensinar o conhecimento historicamente sistematizado pela humanidade, o qual grande parte da população não aprenderá fora dela.

O desenvolvimento (psíquico) ${ }^{3}$ é determinado pelo grau de complexidade requerido nas ações e pela qualidade das mediações disponibilizadas (VIGOSTSKI, 1995 apud MARTINS, 2011). Logo, não ocorrerá com quaisquer aprendizagens, pois "funções complexas não se desenvolvem na base de atividades que não as exijam e possibilitem e essa tarefa deve ser assumida na prática pedagógica por meio da transmissão dos conhecimentos clássicos" (MARTINS, 2011, p. 56).

Outro aspecto que merece ser considerado é que, conforme Marsiglia, Martins e Lavoura (2019, p. 3), “autores como Duarte (2015), Martins (2013), além do próprio Saviani (2011) têm alertado para o fato de não existir ' $a$ ' forma de organização do trabalho didático na pedagogia histórico-crítica". Além disso, conforme Lavoura e Martins (2017, p. 532 apud MARSIGLIA; MARTINS; LAVOURA, 2019, p. 3-4), "tem-se realizado uma 'didatização e desmetodização do método da pedagogia histórico-crítica"”.

É válido pressupor alguns
nexos causais que
possibilitam explicar essa
didatização r e
desmetodização do
método pedagógico
histórico-crítico, quais
sejam: a) a incompreensão
do caráter dialético do
método pedagógico, o que
leva à sua formalização
expressa em passos

\footnotetext{
${ }^{3}$ Sobre a educação escolar e o desenvolvimento do psiquismo ver Martins (2011).
} 
lineares e mecânicos, sequencialmente

sistematizados a partir da lógica formal do pensamento, incorrendose na didatização do ensino; b) a inadequada caracterização do conceito de mediação presente nessa teoria pedagógica (enquanto interposição que gera transformação), comprometendo a compreensão, por exemplo, da relação teoria e prática e da relação forma-conteúdo-

destinatário; c) a falta de clareza na distinção entre método e procedimentos de ensino, com nítida hipertrofia do segundo e secundarização ou abandono do primeiro, levando

consequentemente à desmetodização do próprio método; e d) por fim, um pretenso epistemologismo da pedagogia históricocrítica, de forma intencional ou não, por parte daqueles que $o$ fazem, muito ao gosto da ambiência contemporânea identificada com o debate pós-moderno,

debruçando-se em torno de seus apontamentos didático-metodológicos

sem, no entanto, lançar mão da apropriação de suas bases teóricas e históricas, seus fundamentos filosóficos e o significado político do conjunto da obra de Dermeval Saviani, o que leva à interdição da verdadeira concepção ontológica da pedagogia histórico-crítica.

(LAVOURA; MARTINS, 2017, p. 532 apud MARSIGLIA; MARTINS; LAVOURA, 2019, p. 4).
Enquanto um esforço e uma tentativa de traduzir para a prática docente e discente a pedagogia histórico-crítica, há uma didática elaborada por Gasparin (2007) - tomando como base o método pedagógico elaborado por Saviani -, que considera que o método de investigação e de ensino partem das circunstâncias em que foram produzidos, da realidade material, e que o método, enquanto construção teórica, é expressão e resposta aos desafios postos por determinado período da história dos homens.

Gasparin (2007, p. 3-4) parte da realidade social para discutir a necessidade de uma nova forma do trabalho pedagógico, pois "a leitura crítica da realidade torna possível apontar um novo pensar e agir pedagógicos. Deste enfoque, defende-se o caminhar da realidade social, como um todo, para a especificidade teórica da sala de aula e desta para a totalidade social novamente, tornando possível um rico processo dialético".

Marsiglia, Martins e Lavoura (2019, p. 6), analisam alguns elementos presentes na proposta didática por Gasparin, principalmente no que se refere à apropriação deste autor quanto ao método dialético e suas consequentes transposições didáticas e evidenciam que "o problema relacionado ao método materialista histórico-dialético e os fundamentos didáticos da pedagogia histórico-crítica decorre de uma questão central da obra de Gasparin (2002)", qual seja, "certo equívoco em termos do método dialético no que se refere ao movimento de superação da síncrese à síntese pela análise, reduzindo o fundamento do método a procedimento de ensino, o que tem gerado um conjunto de simplificações, esquematismos e formalização inadequada do método pedagógico em passos estanques e mecanizados" ${ }^{4}$.

Ao explicitar o objeto da educação, Saviani (2011) indica que é preciso levar em conta os elementos culturais que precisam ser apropriados para que os sujeitos se humanizem e, de maneira articulada, as formas de ensino mais adequadas para este fim. Os elementos culturais (traduzidos na escola pelos conteúdos das

\footnotetext{
${ }^{4}$ Sobre o conjunto dos elementos analisados consultar Marsiglia, Martins e Lavoura (2019).
} 
diferentes áreas de conhecimento) precisam atender à dimensão de totalidade, tanto quanto precisam ter em vista o movimento e contradição presentes na realidade concreta, sendo estas três categorias basilares ao método materialista histórico-dialético do qual a pedagogia históricocrítica erige. $\mathrm{O}$ que procuramos chamar atenção é, portanto, que a didática histórico-crítica não pode estar descolada de seus fundamentos e assim, não pode ser pensada de modo lógicoformal, que compartimentaliza e segmenta a compreensão dos fenômenos em geral e, particularmente aqui em foco, o trabalho didático. (MARSIGLIA; MARTINS; LAVOURA, 2019 , p. 7) [grifos dos autores].

Desta forma, com a intencionalidade de "contribuir para a superação do, ainda atual, desafio de desenvolvimento e sistematização dos fundamentos didáticos da pedagogia históricocrítica", Marsiglia, Martins e Lavoura (2019, p. 3), avançam rumo à outra didática histórico-crítica.

Portanto, o trabalho didático não se constitui como receituário a ser seguido, válido eternamente, modelo imutável que desconsidera as especificidades dos diversos campos do conhecimento humano. Considerando o recorte proposto neste estudo, entende-se que uma Didática Crítica e sintonizada com a pedagogia histórico-crítica deve estar fundamentada necessariamente no método que a orienta e, em decorrência, considerar seus elos constituintes. $\mathrm{O}$ docente não pode se furtar de compreender a escola como espaço de contradição, de socialização e de elaboração de conhecimentos, inclusive sobre a própria prática, no protagonismo de conduzi-lo neste espaço de transmissão e de apropriação, por parte dos estudantes, do conhecimento científico, filosófico, artístico-cultural, que é fundamental para a formação humana. Este continua sendo um desafio à educação e um horizonte a ser atingido, de forma massiva.

Os aspectos teóricos discutidos pretendem contribuir, no âmbito da formação inicial e continuada, para que os professores revejam sua ação pedagógica, à luz da importância política da educação cuja função é a socialização do conhecimento, compreendidos os vínculos de sua prática com a prática social global (SAVIANI, 2003). Ademais, conforme Marsiglia (2011b) historiciza sobre seu percurso profissional, uma prática se torna espontaneísta se não há embasamento teórico, igualmente uma teoria se torna vazia se não estiver voltada a responder as questões postas pela prática dos indivíduos.

Não se buscou aqui oferecer um modelo didático a ser operacionalizado no contexto da sala de aula, mas recuperar os elementos que se relacionam e sustentam determinada concepção. Ademais, coadunando com Marsiglia (2011b), é importante mencionar que os procedimentos didáticos a serem utilizados não são propriedade de uma ou outra teoria, uma vez que a diferença está na intencionalidade das ações e não nas operações em si. Ou seja, os procedimentos se ajustam às finalidades.

\section{CONSIDERAÇÕES FINAIS}

Este estudo perseguiu compreender as contribuições da Didática Crítica para a formação docente. Para tanto, no caminho percorrido, ao conceituar e categorizar a Didática e procurar entender sua relação com os métodos e técnicas de ensino e a formação docente, foi possível apreender que a Didática é um elemento importante e crucial na formação docente, pois implica propiciar conhecimentos teóricos e práticos do processo de ensino-aprendizagem, que pode ocorrer sob diferentes concepções, conforme a teoria pedagógica adotada.

A Didática compõe a ciência pedagógica e trata especificamente do ensino, as condições para que ele ocorra, ou seja, sua questão é uma questão metodológica: "Trata-se de criar os meios através dos quais a ciência, o saber sistematizado, traduz-se em conteúdo de ensino, isto é, em conteúdo didaticamente assimilável". Entende-se que, este aspecto é consoante ao apontado por Saviani ao abordar a questão central da Pedagogia. Assim, a relação pedagógica entre os dois sujeitos, professor e estudante, é uma relação mediada pelo 
conhecimento, e essa mediação é metodológica (BOULOS, 1991, p. 96).

Compartilha-se, assim, do indicado por Saviani (2003): a organização pedagógica necessita de uma elaboração coerente especificando conteúdos, métodos, procedimentos técnicos, ou seja, todos os recursos utilizados para que se desenvolva o ensino e aprendizagem em nível de didática.

Entende-se, ainda, que, conforme Frigotto (2011, p. 19), "os processos educativos e a construção do conhecimento estão organicamente vincados às relações sociais e que, na sociedade capitalista cindida em classes sociais antagônicas, esses processos são marcados por uma disputa em seu conteúdo, método e forma". Nesse sentido, para Garutti e Oliveira (2012, p. 2816), “Não será o conteúdo do saber, mas o meio pelo qual este será transmitido que vai transformá-lo em saber conservador e progressista", pois o conhecimento pode ser tratado de forma a contribuir ou negar o processo de humanização.

Para Saviani (2000), não se pode ignorar a categoria de ação recíproca, ou seja, que a educação é determinada de forma relativa pela sociedade, mas o determinado também reage sobre o determinante: a educação também interfere sobre a sociedade, podendo contribuir para sua própria transformação. Compreende-se, assim, que a educação, numa sociedade de classes com interesses antagônicos, tem um caráter contraditório, podendo ser elemento de reprodução ou que impulsione a transformação. No momento em que um destes se realiza o outro é suprimido. Logo, as teorias pedagógicas e suas expressões na prática de ensino, na função da escola, conteúdos de ensino, métodos, relação professor-estudante, pressupostos de aprendizagem e avaliação não são neutras.

Imbricado em dado arcabouço, concebese o fenômeno educativo enquanto parte da realidade, pois a educação é uma prática social, que tem na escola seu lócus principal de realização na atualidade, por meio da educação formal. E, em decorrência, os encaminhamentos sobre o processo de formação humana e as finalidades desta são consoantes à posição de classe em que se insere.

A Didática Crítica tem, em tese, seus fundamentos teórico-metodológicos identificados à tendência pedagógica da concepção histórico-crítica. Por isso, pode contribuir para a formação docente que permita um desenvolvimento pedagógico para além da unilateralidade, ou seja, para a compreensão efetiva da práxis educativa, considerando que a função técnica da educação está subsumida pela função política. Todavia, numa sociedade como a atual, o que predomina de forma hegemônica é a formação unilateral, de um aspecto em detrimento a outros. Não há neutralidade técnica do pensar e fazer pedagógico, pois determinado compromisso político é inerente. 0 compromisso político, pela perpetuação ou transformação de dado estado das coisas, está expresso na forma e no conteúdo do ato pedagógico.

Sobre a elucidação desse aspecto, vale recuperar as preocupações expressas por Fernandes (1987) ao tratar da formação política e o trabalho do professor, que seguem pertinentes no contexto atual da educação brasileira.

A primeira preocupação está ligada à tradição cultural do Brasil e ao que representa na limitação do horizonte cultural do professor, menos na teoria que na prática, na qual o professor é objetificado, brutalizado. Trata-se de um elitismo cultural fechado, no qual "o professor interessava à medida que era um agente puro e simples de transmissão cultural" e sua relação com o estudante era de "preservar os níveis alcançados de realização da cultura por imitação", vendo-o como alguém inferior a ele (FERNANDES, 1987, p. 16). O professor era o intelectual domesticado ou, quando não, elemento de mediação na cadeia de dominação política e cultural, instrumento de dominação localizado nas cadeias mais inferiores do processo. Quanto mais inocente mais acomodável e acomodado, já que "Para essa democracia restrita é dispensável uma cultura cívica e, quando existe alguma coisa parecida com uma cultura cívica, ela é acessível somente àqueles que fazem parte de uma minoria privilegiada, em termos de riqueza, em primeiro lugar, em termos de poder, em segundo lugar, e em termos de saber, em terceiro lugar", ou seja, ignorada às massas (FERNANDES, 1987, p. 18). E, o debate da sua atitude de neutralidade ética com os problemas da vida em com relação aos valores implica a noção de responsabilidade intelectual, com a sociedade, portanto, com a ordem, em que não é colocado numa relação de tensão, mas de acomodação.

A segunda preocupação refere-se a "correlação entre a atividade do professor, numa sociedade subdesenvolvida, e o caráter político do que ele faz e do que deixa de fazer" 
(FERNANDES, 1987, p. 14) o que está vinculado às características peculiares de uma sociedade com desenvolvimento desigual, com contrastes, contradições e problemas com as quais os professores convivem. Sobre essa correlação, Fernandes (1987, p. 25) esclarece que, em qualquer sociedade, a mudança é um processo político, isto é, uma tentativa das classes dominantes de manterem a dominação, das classes intermediárias se associarem em seu proveito à dominação ou alterarem o seu conteúdo e as suas formas. Já em sentido inverso, é uma tentativa das classes subalternas no sentido de modificar ou destruir a dominação.

Ou seja, a mudança interessa tanto ao conservador (para preservar suas posições no poder ou amplifica-las para não correr riscos), como ao reformista (para conquistar posições de poder) ou ao revolucionário (porque se identifica com classes que tem ideias novas sobre a natureza, o conteúdo da civilização e a natureza humana) e requer luta social entre as classes.

A terceira preocupação está em evidenciar o que um marxista pensa em relação a este assunto, ao qual cabe a reflexão de Marx sobre quem educa o educador, pois, "O educador educa os outros, mas ele também é educado. No processo de educar, ele se educa, se reeduca e quando pratica uma má ação no sentido gestaltiano ele se autopune, aprende alguma coisa. A educação do educador é um processo complexo e difícil" (FERNANDES, 1987, p. 33). Nesse processo, pode identificar-se com a classe dominante, com classes intermediárias ou subalternas, e tem "liberdade de escolha, pode ter uma ampla margem de atuação política na sociedade [...] é lamentável que muitos professores usem essa liberdade para se tornarem conservadores e até reacionários [...]" (FERNANDES, 1987, p. 35).

Porém, há potencialidades na realidade, uma vez que é possível conjugar consciência pedagógica dos problemas sociais a uma nova forma de ação prática, garantindo a transformação substantiva. Isso porque, a transformação "não é produto de avanço na esfera da consciência e também não é produto de uma elaboração espontânea da realidade. É preciso que a ação prática transformadora se encadeie a uma consciência teórica e prática, que seja, num sentido ou noutro, dentro da ordem ou contra a ordem, revolucionária" (FERNANDES, 1987, p. 36).
Ao entender que a Didática Crítica está vinculada a uma concepção de educação contrahegemônica, compreende-se que são

[...] 'orientações que não apenas não conseguiam tornar-se dominantes, mas que buscam intencional e sistematicamente colocar a educação a serviço das forças que lutam para transformar a ordem vigente visando a instaurar uma nova forma de sociedade.' São nessas bases teóricas e políticas que, a nosso modo de ver, erguem-se as proposições da didática crítica (SAVIANI, 2008, p. 170 apud FARIA; 2012).

Faria (2012) considera que os pressupostos teóricos da Didática Crítica e de inspiração contra-hegemônica, ancorados no materialismo histórico-dialético, são a chave para compreender os problemas e desafios contemporâneos da Didática, enfrentados na prática dos professores, bem como que:

[...] é pela pesquisa, pelo estudo permanente e pela elaboração teórica dos problemas e desafios vivenciados pela/na prática educativa que se pode avançar na produção do conhecimento no campo da didática, no esclarecimento dos problemas que envolvem o ensino de nossas escolas. Materializando-se na vida escolar como um campo de conhecimento que contribui com as vias de efetivação da função social da escola pública e de qualidade, pois instrumentaliza o professor; no ofício de ensinar; na organização das condições; nos meios; nas situações; e nas atividades didáticas, são potencializadoras da mediação do conhecimento espontâneo dos indivíduos às formas elaboradas da cultura 
como pensado por Saviani

(2005). Assim, comprometem-se com um projeto de formação humana omnilateral (FARIA, 2012, p. 12-13).

O resultado desse compromisso pode ser evidenciado na transformação intelectual qualitativa do docente - e, em decorrência, do estudante -, propiciada por esta orientação e com desdobramentos concretos no desenvolvimento do seu trabalho pedagógico. Para isso, portanto, a formação docente é substancial, uma vez que orientará sua Didática, a partir de dada perspectiva.

É importante, ainda, frisar a negação de um tipo ideal de docente, pois sua ação deve ser uma resposta a necessidades postas pela realidade educacional e sua formação não se concretiza de uma só vez, já que esta é processo, "É o resultado de condições históricas. Faz parte necessária e intrínseca de uma realidade concreta determinada. Realidade esta que não pode ser tomada como alguma coisa pronta, acabada ou que se repete indefinidamente" (FÁVERO, 1981, p. 19 apud CANDAU; LELIS, 1995, p. 61).

Por conseguinte, na Didática Crítica, ou na didática vinculada à pedagogia históricocrítica, ao estar relacionada à transformação das atuais relações de exploração, o docente utiliza em sua prática pedagógica instrumentos, meios, técnicas, estratégias e formas que favoreçam que o conhecimento historicamente produzido, sistematizado e elaborado pela humanidade seja apropriado pelos estudantes e seu compromisso com o ensino relaciona-se aos interesses da classe trabalhadora.

\section{REFERÊNCIAS}

ALVES, Gilberto Luiz. Trabalho didático na escola moderna: formas históricas. Campinas, São Paulo: Autores Associados, 2005.

ALVES, Gilberto Luiz. Formação de professores: uma necessidade de nosso tempo? Revista HISTEDBR On-line, Campinas, n. 31, p. 102-112, $2008 . \quad$ Disponível em: http://www.histedbr.fe.unicamp.br/revista/edico es/31/art08 31.pdf. Acesso em: 17 de mar. de 2015.
ARAÚJO, José Carlos Souza. Do quadro-negro à lousa virtual: técnica, tecnologia e tecnicismo. In: VEIGA, Ilma Passos Alencastro (Org.) Técnicas de Ensino: novos tempos, novas configurações. Campinas, SP: Papirus, 2006. p. 13-48.

BOULOS, Yara. Didática geral ou especial? Uma contribuição ao debate. In: FAZENDA, Ivani Catarina; et al. A prática de ensino e o estágio supervisionado. Campinas, SP: Papirus, 1991. p. 91-99.

CANDAU, Vera Maria. A didática em questão. Petrópolis: Vozes, 1987.

CANDAU, Vera Maria; LELIS, Isabel Alice. A relação teoria-prática na formação do educador. In: CANDAU, Vera Maria. Rumo a uma nova didática. 7 ed. Petrópolis: Vozes, 1995. p. 56-72.

CASTRO, Amélia D. A Trajetória Histórica da Didática. Série Idéias, n.11. São Paulo: FDE, 1991. Disponível

em: www.crmariocovas.sp.gov.br/amb. Acesso em: 20 de mar. de 2006.

DEMO, Pedro. Metodologia para quem quer aprender. São Paulo: Atlas, 2008.

FREITAS, Luiz Carlos de. Crítica da organização do trabalho pedagógico e da Didática. Campinas, SP: Papirus, 1995.

DUARTE, Newton. Sociedade do Conhecimento ou Sociedade das llusões? Campinas: Autores Associados, 2008

FACCI, Marilda Gonçalves Dias. A crítica às pedagogias do "aprender a aprender": a naturalização do desenvolvimento humano e a influência do construtivismo na educação. In: MARSIGLIA, Ana Carolina Galvão (Org). Pedagogia histórico-crítica: 30 anos. Campinas, SP: Autores Associados, 2011. p. 121-146.

FARIA, Lenilda Rêgo Albuquerque de. As orientações educativas contra-hegemônicas em face dos questionamentos pós-modernos. E a didática com isso? In: Encontro Nacional de Didática e Práticas de Ensino - ENDIPE, 15, 2012. Anais... UNICAMP, Campinas 2012.

EXCLUI UM DOS DOIS ESPAÇOS FERNANDES, Florestan. A formação política e o trabalho do professor. In: CATANI, Denice 
Bárbara; MIRANDA, Hercília Tavares de; MENEZES, Luis Carlos de; FISCHMANN, Roseli (Orgs). Universidade, escola e formação de professores. São Paulo: Brasiliense, 1987. p. 1337.

FREITAS, Luiz Carlos de. Crítica da organização do trabalho pedagógico e da Didática. Campinas: Papirus, 1995.

FRIGOTTO, Gaudêncio. Projeto societário contrahegemônico e educação do campo: desafios de conteúdo, método e forma. In: MUNARIN, Antônio; BELTRAME, Sônia; CONTE, Soraya Franzoni; PEIXER, Zilma Isabel (orgs). Educação do Campo: reflexões e perspectivas. 2. ed Florianópolis: Insular, 2011. p. 19-46.

GARUTTI, Celso; OLIVEIRA, Rita de Cássia da Silva. Método Didático do Materialismo Histórico na Educação. In: SEMINÁRIO NACIONAL DE ESTUDOS E PESQUISAS HISTÓRIA, SOCIEDADE E EDUCAÇÃO NO BRASIL, 11, 2012. Anais... João Pessoa-PB, $2012 . \quad$ Disponível em http://www.histedbr.fae.unicamp.br. Acesso em: 10 de jan. de 2014.

GASPARIN, João Luiz. Uma didática para a pedagogia histórico-crítica. 4 ed. Campinas, SP: Autores Associados, 2007.

GASPARIN, João Luiz; PETENUCCI, Maria Cristina. Pedagogia Histórico-Crítica: Da teoria à prática no contexto Escolar. Paraná: 2007. Disponível em: http://www.diadiaeducacao.pr.gov. Acesso em: 20 de out. de 2012.

KONDER, Leandro. 0 que é dialética. São Paulo: Brasiliense, 2008.

LIBÂNEO, José Carlos. Democratização da escola pública: a pedagogia crítica social dos conteúdos. São Paulo: Loyola, 1984.

LIBÂNEO, José Carlos. Didática. São Paulo: Cortez, 1994.

LIBÂNEO, José Carlos. Educação: Pedagogia e Didática. O campo investigativo da pedagogia e da didática no Brasil: esboço histórico e buscas de identidade epistemológica e profissional. In: PIMENTA, Selma Garrido (Org.). Didática e Formação de Professores: percursos e perspectivas no Brasil e em Portugal. São Paulo: Cortez, 2006.

LÜDKE, Menga; ANDRÉ, Marli Eliza Dalmazo Afonso de. Pesquisa em Educação: Abordagens qualitativas. São Paulo: EPU, 1986.

MARSIGLIA, Ana Carolina Galvão. A pedagogia histórico-crítica no contexto da educação brasileira. In: Congresso Brasileiro de História da Educação, 6, 2011, Anais... Vitória-ES: UFES, 2011a. p. 1-13. Disponível em: https://doi.org/10.20396/rho.v19i0.8653380.

Acesso em: 15 mar. 2019.

MARSIGLIA, Ana Carolina Galvão. A prática pedagógica na perspectiva da pedagogia histórico-crítica. In: MARSIGLIA, Ana Carolina Galvão (Org). Pedagogia histórico-crítica: 30 anos. Campinas, SP: Autores Associados, 2011b. p. 101-120.

MARSIGLIA, Ana Carolina Galvão; MARTINS, Lígia Márcia; LAVOURA, Tiago Nicola. Rumo à outra didática histórico-crítica: superando imediatismos, logicismos formais e outros reducionismos do método dialético. Revista HISTEDBR On-line, Campinas, v. 19, n. 28, p. 1-28, jan./abr. 2019. Disponível em: https://periodicos.sbu.unicamp.br/ojs/index.php /histedbr. Acesso em: 15 mar. 2019.

MARTINS, Lígia Marcia. Pedagogia históricocrítica e psicologia histórico-cultural. In: MARSIGLIA, Ana Carolina Galvão (Org). Pedagogia histórico-crítica: 30 anos. Campinas, SP: Autores Associados, 2011. p. 43-57.

MARTINS, Pura Lúcia. A didática e as contradições da prática. Campinas: Papirus, 1998.

MARX, Karl; ENGELS, Friedrich. Textos sobre educação e ensino. 2. ed. São Paulo: Moraes, 1992.

MARX, Karl; ENGELS, Friedrich. A ideologia alemã. São Paulo: Boitempo, 2007.

MARX, Karl. O Capital: crítica da Economia Política. Vol. 3, tomo 2. São Paulo: Abril Cultural, 1985. 
RAYS, Oswaldo Alonso. Razões da razão didática: hipóteses para a construção de uma didática escolar crítica. Olhar de professor, Ponta Grossa, v. 11, n. 1, p. 11-21, 2008. Disponível em: https://doi.org/10.5212/OlharProfr.v.11i1.01102 1. Acesso em: 15 mar. 2018.

SAVIANI, Dermeval. Pedagogia Histórico-Crítica: primeiras aproximações. 7 ed. Campinas: Autores Associados, 2000.

SAVIANI, Dermeval. Escola e Democracia: teorias da educação, curvatura da vara, onze teses sobre educação e política. Campinas: Autores Associados, 2003.

SAVIANI, Dermeval. Pedagogia: o espaço da educação na universidade. Cadernos de Pesquisa, v. 37, n. 130, p. 99-134, 2007. Disponível em: https://doi.org/10.1590/S010015742007000100006. Acesso em: 20 de mar. de 2019.

SAVIANI, Dermeval. História das Ideias Pedagógicas no Brasil. 2. ed. Campinas, SP: Autores Associados, 2008. p. 197-225.

SAVIANI, Dermeval. Antecedentes, origem e desenvolvimento da pedagogia histórico-crítica. In: MARSIGLIA, Ana Carolina Galvão (Org). Pedagogia histórico-crítica: 30 anos. Campinas, SP: Autores Associados, 2011. p. 197-225.

SAVIANI, Dermeval. Marxismo, educação e pedagogia. In: SAVIANI, Dermeval; DUARTE, Newton. Pedagogia-histórico-crítica e luta de classes na educação escolar. Campinas, SP: Autores Associados, 2012. p. 223-274.

SAVIANI, Dermeval. O conceito dialético de mediação na Pedagogia Histórico-Crítica em intermediação com a Psicologia HistóricoCultural. Germinal: Marxismo e Educação em Debate, Salvador, v. 7, n. 1, p. 26-43, jun. 2015. Disponível em: https://doi.org/10.9771/gmed.v7i1.12463.

Acesso em: 20 de jun. de 2019.

SAVIANI, Nereide. Currículo: um grande desafio para o professor. Revista de Educação, São Paulo, n. 16, p. 35-38, 2003.

SEVERINO, Antônio Joaquim. Metodologia do trabalho científico. São Paulo: Cortez, 2007.
TAVARES, Rosilene Horta. A Didática crítica frente ao toyotismo e às tecnologias informacionais. In: Reunião Anual da Anped. 31, 2008. Anais... Caxambu, MG, 2008. Disponível em: http://www.anped.org.br/sites/default/files/gt04 -5042-int.pdf. Acesso em 26 de mar. de 2019.

VEIGA, Ilma Passos Alencastro. A prática pedagógica do professor de Didática. Campinas: Papirus, 1994.

VEIGA, IIma Passos Alencastro. Repensando a Didática. Campinas: Papirus, 2004. 